\title{
IPTEKS PERLAKUAN AKUNTANSI TERHADAP PENGHENTIAN DAN PELEPASAN ASET TETAP PADA KANTOR LURAH KLEAK
}

\author{
Gandi Mararu ${ }^{1}$, Winston Pontoh ${ }^{2}$ \\ ${ }^{1,2}$ Jurusan Akuntansi, Fakultas Ekonomi dan Bisnis Universitas Sam Ratulangi, Jl. Kampus Unsrat, Manado, \\ 95115, Indonesia \\ email : gandimararu@gmail.com
}

\begin{abstract}
Fixed assets are one of several conditions that can support the success of companies and agencies. With adequate fixed assets, the smooth running of the business and operational activities of a company or agency can run well. The Kleak village office must have fixed assets that have expired, obsolete, and economically depleted, and whether the Kleak village office has released and terminated the assets according to PSAK NO. 16. The result shows that Kleak vilage office has never terminated and released the fixed assets which have expired or have been obsolete.
\end{abstract}

Keywords: Release of fixed assets, PSAK NO. 16

\section{PENDAHULUAN}

Aktiva tetap menjadi syarat utama yang agar instansi dapat menjalankan kegiatan opersional instansi. Dengan memiliki aktiva tetap yang memadai maka kelancaran aktivitas operasional dari suatu instansi dapat berjalan dengan baik. Sebaliknya, jika suatu intansi tidak memilki aktiva tetap yang memadai maka akan berpengaruh terhadap kegiatan operasional instansi dalam melakukan pelayanan yang optimal bagi masyarakat. Jadi aktiva tetap yang dimiliki perusahaan ,untuk tujuan penggunaan lebih dari satu tahun dan bukan tujuan untuk dijual tapi untuk digunakan kegiatan operasional instansi tersebut.

Instansi yang baik dapat menyusun laporan keuangan berdasarkan Standar Akuntansi Keuangan yang digunakan sebagai dasar dalam menyajikan laporan keuangan instansi tersebut. Laporan keuangan tersebut dapat memenuhi kebutuhan informasi dari pengguna laporan keuangan baik untuk internal maupun pihak eksternal instansi. Untuk mendukung kegiatan operasional instansi, setiap instansi pasti memiliki faktor-faktor pendukung dalam memberikan pelayanan untuk menghasilkan pelayanan yang optimal contohnya memerlukan peralatan kator untuk meongoptimalkan pelayanan kepada masyarakat. Salah satu faktor pendukung dalam kegiatan operasional atau pelayanan instansi adalah aset tetap instansi tersebut. Aset tetap yang ada di instansi merupakan bagian yang yang sangat penting dalam memberikan pelayanan yang optimal bagi masyarakat. Untuk mengoptimalkan peranan tersebut maka aset tetap membutuhkan pengelolaan yang baik dari pihak intansi dengan menggunakan kebijakan yang berlaku. Para pengambil keputusan umumnya membutuhkan informasi atas aset tetap berupa daftar aset tetap dan akumulasi penyusutannya seperti yang tersaji dalam laporan keuangan. Atas dasar tujuan ini maka aset tetap yang disajikan dalam laporan keuangan sebaiknya menggunakan standar akuntansi keuangan yang berlaku.

Aset tetap bisa dimiliki dengan beberapa cara ada yang dibeli secara tunai, ada yang dibeli secara hutang usaha atau kredit dengan cara pembayaran dengan cara diansur,dengan cara ditukar dengan aset lain, dengan cara diterbitkan surat berharga, dibangun sendiri,disewa dari pihak yang menyewakan dan dari donasi berbagai pihak, aset tetap yang sudah habis masa ekonomisnya,yang telah dijual,dan yang telah usang karena kemajuan teknologi serta telah habis disusutkan masa ekonomisnya harus diadakan penghentian aset tetap sesuai dengan umurnya dan masa manfaatnya. Kantor Kelurahan Kleak umumnya masih memiliki aset tetap yang telah habis masa manfaatnya, telah usang, dan habis umur 
ekonomisnya, dan apakah pihak kantor kelurahan telah menerapkan PSAK No. 16 untuk halhal tersebut.

\section{TINJAUAN PUSTAKA}

Akuntansi. Menurut Wild, Shaw dan Chiappetta (2014:3) akuntansi merupakan sistem yang menyajikan informasi tentang pengukuran, pencatatan dan informasi yang relevan, terpercaya, dan memiliki keterbandingan atas kegiatan bisnis organisasi. Menurut Kartikahadi (2015:3), akuntansi adalah sebuah sistem yang menyajikan informasi keuangan dengan tujuan menghasilkan dan melaporkan informasi yang reliabel dan efisien bagi pihak yang berkepentingan. Dari beberapa penjelasan diatas dapat disimpulkan bahwa akuntansi merupakan proses penyajian, pengukuran, pencatatan dan penyampaian informasi keuangan yang relevan dan dapat dipercaya bagi pihak-pihak yang berkempentingan dalam pengambilan keputusan ekonomi.

Laporan keuangan. Menurut Kasmir (2016:7), laporan keuangan merupakan informasi data keuangan sebuah perusahaan atau instansi pada suatu periode. Menurut Pernyataan Standar Akuntansi Keuangan (PSAK) No. 1 paragraf 10 (revisi 2016) laporan keuangan yang baik yaitu memiliki: (a) laporan pada akhir periode tentang posisi keuangan perusahaan; (b) laporan selama periode tentang laporan laba rugi dan pendapatan komprehensif; (c) ekuitas dan perubahannya untuk periode tertentu; (d) laporan selama periode mengenai arus kas; (e) CALK, yang berisi informasi tentang kebijakan akuntansi atas periode pelaporan seperti yang ditentukan pada paragraf 38 dan 38A; dan (f) laporan pada awal periode terdekat yang berisi informasi posisi keuangan.

Aset tetap. Pradana (2015) menjelaskan bahwa aset tetap merupakan kekayaan berwujud yang dimiliki perusahaan yang memiliki serta dapat memberikan penghasilan yang berasal dari aktivitas investasi yang dilakukan perusahaan. Aset tetap memberikan kegunaan ekonomi kepeda perusahaan selama lebih dari satu tahun serta memiki wujud fisik. Lubis (2017:29) mengungkapkan bahwa aset tetap adalah aset yang dimiliki dan digunakan perusahaan yang jangka waktunya lebih dari satu tahun dan mempunyai masa manfaat yang mempunyai nilai susut (penurunan nilai guna). Beberapa pengertian menunjukkan bahwa sebuah aset dapat diklasifikasikan sebagai aset tetap apabila mempunyai wujud fisik, dan mempunyai umur kegunaan satu tahun atau lebih.

Klasifikasi aset tetap. Dalam PSAK No. 16 paragraph 37 asset tetap diklasifikasikan menurut kegunaan dan kelasnya. Berikut ini merupakan jenis aset tetap: tanah, tanah dan bangunan, mesin, kapal laut, pesawat terbang, kendaraan, perabot, dan perlengkapan kantor.

Cara perolehan aset tetap. Menurut Hery (2014:125), Selain dibeli secara tunai, aset juga dapat diperoleh melalui : (1) pembelian gabungan; (2) pembelian kredit; (3) sewa guna usaha modal; (4) pertukaran aset tetap; (5) penerbitan sekuritas; (6) konstruksi (bangun) sendiri; dan (7) donasi (sumbangan).

\section{Pengukuran aset tetap}

a. Pengukuran awal. Menurut Martani (2016:272) pengukuran aset tetap dapat menggunakan harga perolehan saat pertama kali diperoleh. Komponen nilai perolehan aset tetap adalah: (1) harga perolehan termasuk bea impor atau pajak yang tidak dapat dikreditkan setelah dikurangi diskon pembelian dan potongan lainnya; (2) biaya-biaya langsung terkait perolehan aset tersebut; dan (3) perkiraan awal atas biaya pembongkaran, pemindahan, dan restorasi lokasi aset.

b. Pengukuran setelahnya. Setelah dilakukan pengakuan awal atas aset tetap, tergantung kebijakan akuntansi yang di terapkan instansi tersebut bisa saja instansi mengunakan model revaluasi atau model biaya dan sekali lagi ini tergantung kebijakan perusahaan atau instansi tersebut. Jika instansi tersebut memilih model biaya maka semuat aset harus diukur menggunakan model biaya. 
Pengungkapan aset tetap. Menurut Suwardjono (2014:578), pengungkapan adalah salah satu bagian yang penting dari pelaporan keuangan, karena pengungkapan adalah proses akhir dalam proses dalam penyajian informasi akuntansi yang berisi informasi yang lengkap tentang laporan keuangan.

Penghentian pengakuan dan pelepasan aset tetap. Dalam paragraph 67 pada PSAK 16 revisi tahun 2016 menyatakan bahwa aset tercatat dihentikan pengakuanya: (a) pada saat pelepasan; atau (b) saat penggunaanya tidak memberikan manfaat ekonomis dimasa depan. Pelepasan aset tetap dapat dilakukan dengan berbagai cara yaitu: (1) dijual; (2) dihapus aset tetap dari semua rekening yang bersangkutan; (3) disewakan atau disumbangkan; dan (4) ditukar dengan aset lain.

Penyajian aset tetap. Menurut PSAK No. 1 dalam laporan keuangan, berisi neraca, dan neraca laporan suatu periode tertentu yang berisi komposisi harta, modal, dan kewajiban. Ernawati (2014) menjelaskan bahwa laporan posisi keuangan memuat harga perolehan aset tetap, akumulasi penyusutan, dan nilai bukunya.

Penelitian terdahulu. Pontoh, Morasa, dan Budiarso (2016) menerapkan perlakuan akuntansi atas aset tetap menurut PSAK NO.16 pada PT. Nichindo Manado Suisan.

\section{METODE DAN TEKNIK PENERAPAN IPTEKS}

\subsection{Metode Penerapan Ipteks}

Metode ipteks yang digunakan adalah perlakuan akuntansi atas penghentian dan pelepasan aset tetap menurut PSAK NO. 16.

\subsection{Teknik Penerapan Ipteks}

Teknik Iptek yang diterapkan adalah pelepasan dan penghentian aset tetap berdasarkan standar akuntansi yang berlaku yaitu PSAK No. 16. yaitu aset tetap akan dilpasakan apabila aktiva tersebut suda habis masa ekonomisnya,ditukar dengan aset yang sejenis atau telah usang karena kemajuan teknologi.

\section{PEMBAHASAN}

\subsection{Gambaran Objek Penerapan Ipteks}

Kecamatan Malalayang kota Manado memiliki sembilan kelurahan salah satunya adalah kelurahan kleak. Kelurahan Kleak adalah hasil pemekaran dari desa Bahu Kecamatan Sario pada tahun 1978, pada waktu itu Desa Bahu dibagi menjadi Desa Bahu dan Desa Kleak. Pada tahun 1981 menteri dalam negeri mengeluarkan keputusan Menteri nomor 41 .Maka status desa yang berbeda kotamadya dan di ibu kota kabupaten berubah menjadi Kelurahan, pada akhirnya Kelurahan Kleak berubah menjadi Kecamatan Malalayang, dan Kelurahan Kleak dibagi menjadi lima lingkungan. Pada tahun 2010, Kelurahan Kleak di sahkan menjadi Kelurahan Kleak dan Kelurahan Batu Kota. Pada saat ini Kota Manado telah memiliki 87 kelurahan salah satunya Kelurahan Kleak.

\subsection{Pembahasan}

Berdasarkan penelitian yang dilakukan untuk penghentian aset tetap dari penggunanya oleh kantor Kelurahan Kleak didapati bahwa pihak kantor Kelurahan Kleak tidak pernah melakukan penghentian aset tetap.jelas ini belum sesuai dengan standar akuntansi yang berlaku yang menyatakan aset tetap dilepas atau dihentikan pengakuanya pada saat dijual,telah habis masa kegunaanya sudah usang karena kemajuan teknologi. Laba akibat pelapasan aset tetap dimasukan dalam laporan laba rugi ketika aset tetap tersebut dilepaskan kecuali transaksi jual sewa balik. Laba bukan dari pelapasan aset bukan pendapatann. Pihak instansi tidak pernah melakukan penghentian dan pelepasan aset tetap hal tersebut di lihat dari 6 (enam) contoh transaksi dari daftar aset tetap kelurahan dari tahun 2011 s/d 2016, ada beberapa aset tetap kelurahan telah habis umur ekonomisnya (nilai 
perolehan sudah habis di susutkan),tetapi masih ada di dalam daftar aset tetap kantor kelurahan.

\section{KESIMPULAN DAN SARAN}

\subsection{Kesimpulan}

Penghentian dan pelepasan aset tetap tidak pernah dilakukan oleh pihak perusahaan, hal tersebut mempengaruhi laporan keuangan Kantor Kelurahan.

\subsection{Saran}

Perlunya pengetahuan akuntansi dalam menerapkan pencatatan pelepasan dan penghentian aset tetap dari kantor kelurahan, sehingga aktivitas kelurahan bisa berjalan efektif dan efisien khususnya penyajian aset tetap dalam laporan keuangan sesuai dengan standar akuntansi yang berlaku.

\section{DAFTAR PUSTAKA}

Ernawati. 2014. Analisis Penerapan Standart Akuntansi Keuangan (PSAK No.16) Atas Aset Tetap Pada PT.Pelayaran Liba Marindo Tanjung Pinang. Universitas Maritim Raja Ali Tanjung Pinang.

Hery. 2014. Akuntansi Aset, Liabilitas, dan Ekuitas. PT Gramedia Widiasarana Indonesia. Jakarta.

Ikatan Akuntan Indonesia (IAI). 2016a. Penyajian Laporan Keuangan. Pernyataan Standar Akuntansi Keuangan No.1. (Revisi 2015). DSAK-IAI. Jakarta

Ikatan Akuntan Indonesia (IAI). 2016b. Aset Tetap. Pernyataan Standar Akuntansi Keuangan No.16. (Revisi 2015). DSAK-IAI. Jakarta.

Kartikahadi, Hans., Sinaga, Uli Rosita., Syamsul, Merliyana., Siregar, Sylvia Veronica.,Wahyuni, Ersa Tri. 2015. Akuntansi Keuangan Berdasarkan SAK Berbasis IFRS. Edisi Kedua. Buku 1. Penerbit Ikatan Akuntan Indonesia. Jakarta.

Kasmir. 2016. Analisis Laporan Keuangan. Raja Grafindo Persada. Jakarta

Lubis, Rahmat Hidayat. 2017. Pengantar Akuntansi Jasa. Penerbit Gava Media. Yogyakarta.

Martani. Dwi., Sylvia Veronica Siregar., Ratna Wardhani., Aria Farahmita., Edward Tanujaya. 2016. Akuntansi Keuangan Menengah Berbasis PSAK (PSAK Konvergensi IFRS). Edisi 2 Buku 1. Penerbit Salemba Empat. Jakarta Selatan

Pontoh, E. L., Morasa, J., dan Budiarso, N. S.. 2016. Evaluasi Penerapan Perlakuan Akuntansi Terhadap Aktiva Tetap Berdasarkan PSAK No.16 Tahun 2011 pada PT. Nichindo Manado Suisan. Universitas Sam Ratulangi Manado. Jurnal Emba ISSN 2303-1174. Vol.4.

Pradana, Yoga \& Tuban Drijah Herawati. 2015. Penerapan PSAK No.16 tentang Aset Tetap pada PT. Perkebunan Nusantara XI (Persero) PG Seodhono Ngawi. Jurnal Ilmiah Mahasiswa FEB Universitas Brawijaya Malang. Volume 3 No.1.

Suwardjono. 2014. Teori Akuntansi Perekayasaan Pelaporan Keuangan , Edisi ketiga cetakan kedelapan.BPFE Yogyakarta,Yogyakarta

Wild, J.J., K.W. Shaw, B. Chiappettadan W. Kwok, 2014, Financial Accounting, 2 ed.,McGraw-Hill Education, Amerika Serikat 